\title{
Peningkatan Pertumbuhan dan Produksi Beberapa Varietas Kedelai (Glycine max (L) Merrill.) Melalui Pemberian Pupuk Solid Limbah Kelapa Sawit
}

\author{
Nurbaiti Amir ${ }^{1}$, Berliana Palmasari ${ }^{*}$, dan Bobby Merlan Bangun ${ }^{3}$ \\ 1,2,3 Program Studi Agroteknologi Fakultas Pertanian \\ Universitas Muhammadiyah Palembang \\ Jalan Jenderal Ahmad Yani 13 Ulu Palembang, 30265 \\ ${ }^{1}$ Email: nurbaitiamir@gmail.com \\ 2 Email: berlianadiali10@gmail.com \\ *Penulis korespondensi: berlianadiali10@gmail.com
}

\begin{abstract}
Soybean a potential crop needs to be developed, because it's a large market opportunity in South Sumatra it's not been widely cultivated and still low production. Research aimed was to determine and obtain varieties and solid fertilizer dosage the most influential on growth and soybean (Glycine max (L) Merrill) Production. Resrach used an experimental Split Plot Design method. The First Factor (Main Plot) Soybean Varieties (V), namely $V_{1}=$ Wilis; $V_{2}=$ Tanggamus and $V_{3}=$ Anjasmoro and the second factor (Sub-plot) Solid Fertilizer (S), namely $S_{1}=15$ tons ha-1; S2 $=30$ tons ha- ${ }^{-1}$ and $S_{3}=45$ tons ha ${ }^{-1}$. Research was conducted on farmer's land in Sukajadi Urban Village, Talang Kelapa Banyuasin Sub-district, from September to December 2020. The Anova results showed that the treatment of varieties and solid fertilizers nor interactions it's a significant up to significantly effect on all observed variables. Anjasmoro variety it's the best yield of soybean plant growth with the highest plant height $(64.32 \mathrm{~cm})$, the number of productive branches (9.67 branches), and Wilis variety it's the best yield of soybean production with the best seed weight per plant $(84.11 \mathrm{~g})$, the best seed weight per plot $(683.67 \mathrm{~g})$, solid fertilizer with a dosage 30 tons ha ${ }^{-1}$ gave the best results on the growth and production of soybean plants. Interaction between the Wilis variety and solid fertilizer dosage 30 tons ha ${ }^{-1}$ gave the best yield on soybean production $783.00 \mathrm{~g} /$ plot or equivalent to 2.08 tons ha $^{-1}$.
\end{abstract}

Keywords: Growth, Production, Solid Fertilizer, Soybean Plant, Varieties

\begin{abstract}
ABSTRAK
Kedelai merupakan tanaman potensial yang perlu dikembangkan, karena memiliki peluang pasar yang besar di Sumatera Selatan belum banyak dibudidayakan dan produksinya pun masih rendah. Penelitian ini bertujuan untuk mengetahui dan mendapatkan varietas dan dosis pupuk solid yang berpengaruh terbaik terhadap pertumbuhan dan produksi tanaman kedelai (Glycine max (L) Merrill). Penelitian ini menggunakan metode eksperimen dengan Rancangan Petak Terbagi (Split Plot Design). Faktor yang Pertama (Petak Utama) Varietas Kedelai $(\mathrm{V})$ yaitu $\mathrm{V}_{1}=$ Wilis; $\mathrm{V}_{2}=$ Tanggamus dan $\mathrm{V}_{3}=$ Anjasmoro sedangkan Faktor kedua (Anak Petak) Pupuk Solid (S) yaitu $S_{1}=15$ ton ha- $S_{2}=30$ ton ha ${ }^{-1}$ dan $S_{3}=45$ ton ha- ${ }^{-1}$. Penelitian ini telah dilaksanakan pada lahan petani di Kelurahan Sukajadi, Kecamatan Talang Kelapa Banyuasin, pada bulan September sampai Desember 2020. Hasil analisis keragaman (Anova) bahwa perlakuan varietas dan pupuk solid maupun interaksinya berpengaruh nyata sampai sangat nyata terhadap semua peubah yang diamati. Varietas Anjasmoro memberikan hasil terbaik pertumbuhan tanaman kedelai dengan tinggi tanaman tertinggi $(64,32 \mathrm{~cm})$, jumlah cabang produktif terbanyak $(9,67$ cabang), sedangkan varietas Wilis memberikan hasil terbaik produksi tanaman kedelai dengan berat biji per tanaman terbaik $(84,11 \mathrm{~g})$, berat biji per petak terbaik $(683,67 \mathrm{~g})$, pupuk solid dengan dosis 30 ton ha ${ }^{-1}$ memberikan hasil terbaik terhadap pertumbuhan dan produksi tanaman kedelai.
\end{abstract}


Interaksi antara varietas Wilis dan pupuk solid dosis 30 ton ha ${ }^{-1}$ memberikan hasil terbaik terhadap produksi tanaman kedelai sebesar $783,00 \mathrm{~g} /$ petak atau setara dengan 2,08 ton ha $^{-1}$.

Kata kunci: Pertumbuhan, Produksi, Pupuk Solid, Tanaman Kedelai, Varietas

\section{Pendahuluan}

Kedelai (Glycine max (L) Merrill) termasuk tanaman kacang-kacangan menjadi andalan nasional karena merupakan sumber protein nabati yang sangat penting dalam rangka peningkatan gizi masyarakat karena aman bagi kesehatan dan murah harganya (Hasanuddin et al., 2005). Selain sebagai produk makanan, kedelai juga digunakan sebagai bahan baku industri, bahan penyegar bahkan limbah dari olahan kedelai dapat dimanfaatkan untuk pakan ternak (Riawati et al., 2016).

Menurut Badan Pusat Statistik (2019), produksi kedelai di Indonesia pada tahun 2017 sebesar 538.728 ton dan tahun 2018 sebesar 982.598 ton. Berdasarkan data Dinas Tanaman Pangan dan Hortikultura Sumatera Selatan (2019), rerata produksi kedelai di Sumatera Selatan sebesar 14,95 ton. Peningkatan produksi kedelai masih belum memenuhi mengingat jumlah psenduduk 257,6 juta jiwa dan besarnya minat masyarakat akan konsumsi pangan yang berbahan baku kedelai dan kesadaran akan kebutuhan protein nabati, maka komoditas kedelai prioritas untuk dikembangkan dalam negeri.

Rendahnya produktivitas kedelai dapat diminimalisasi diantaranya dengan perbaikan teknik budidaya melalui penggunaan varietas unggul dan pemupukan. Ada beberapa langkah praktis yang biasa dilakukan untuk meningkatkan produktivitas kedelai, misalnya penggunaan pupuk secara efisien, waktu tanam yang tepat, daya dukung lahan yang sesuai, serta penggunaan varietas unggul yang memiliki daya adaptasi yang tinggi atau luas pada berbagai agroekosistem (Martodireso \& Suryanto, 2001).

Penggunaan varietas unggul paling mudah dan cepat menyebar karena kontribusinya yang penting dalam meningkatkan produktivitas dan relatif mudah diterima oleh petani. Varietas unggul kacang kedelai diantaranya Wilis produktivitas 1,6 ton ha-1 dengan umur panen 85-90 hari, tahan terhadap karat daun dan virus, Tanggamus ukuran biji sedang, produktivitas 1,22 ton ha ${ }^{-1}$ dengan umur panen 88 hari. Anjasmoro ukuran biji besar, produktivitas 2,03-2,25 ton ha-1 dengan umur panen 82-92 hari (Balitkabi, 2017).

Berdasarkan hasil penelitian Sari et al., (2014), menunjukkan bahwa varietas Wilis menghasilkan bobot kering 100 biji yang tertinggi dari kemampuan potensi hasilnya, sedangkan varietas Anjasmoro menghasilkan pertumbuhan vegetatif tertinggi yaitu pada peubah tinggi tanaman $(41,40 \mathrm{~cm})$. Penelitian Sabrina et al., (2018), varietas Tanggamus menunjukkan hasil tertinggi pada peubah jumlah polong per tanaman, jumlah biji per tanaman, bobot biji per tanaman dan produksi (ton ha-1). Hasil penelitian Balitkabi (2017), hasil tertinggi didapat pada varietas Anjasmoro dengan produksi rerata 2,03-2,25 ton ha-1. Namun varietas unggul pada umumnya membutuhkan input yang lebih besar. Hal ini yang 
menyebabkan pertumbuhan tanaman kedelai membutuhkan pengelolaan unsur hara, terutama hara $\mathrm{P}$ yang merupakan salah satu pembatas utama pertumbuhan tanaman. Ketersediaan unsur hara di dalam tanah cenderung berkurang karena adanya pencucian unsur hara oleh karena itu untuk memenuhi kebutuhan hara bagi tanaman perlu dilakukan pemupukan.

Pemupukan merupakan kegiatan utama dalam pemeliharaan tanaman untuk mendapatkan pertumbuhan dan produksi yang optimal. Pemupukan dapat dilakukan melalui pemberian pupuk organik maupun anorganik. Pemanfaatan pupuk organik dapat memperbaiki sifat fisik, kimia dan biologi tanah. Pupuk organik yang dapat digunakan salah satunya pemanfaatan solid (Novizan, 2005).

Solid adalah limbah padat dari proses pengolahan buah kelapa sawit menjadi minyak mentah kelapa sawit atau Crude Palm Oil (CPO) yang memakai sistem decanter. Decanter digunakan untuk memisahkan fase cair (minyak dan air) dari fase padat sampai partikel-partikel terakhir. Solid dilepaskan dari decanter yang terdiri dari lumpur dengan kelembaban tinggi. Solid mentah memiliki warna cokelat dan masih mengandung minyak CPO sekitar 1,5\% (Pahan, 2008).

Hasil analisis menunjukkan bahwa padatan solid memiliki kandungan bahan kering $81,56 \%$, dimana kandungan bahan kering ini terdapat protein kasar $12,63 \%$, serat kasar 9,98\%, lemak kasar 7,12\%, kalsium 0,03\%, Fosfor 0,003\%, dan energi $154 \mathrm{kal} / 100 \mathrm{~g}$ (Utomo dan Widjaja, 2004). Solid asal limbah kelapa sawit mempunyai kandungan $\mathrm{N}$ (3,52\%), P (1,97\%), K (0,33\%) dan Mg (0,49\%) (Pusat Penelitian Kelapa Sawit, 2009).

Hasil penelitian Idris \& Okalia (2018), menunjukkan pemberian pupuk solid dengan takaran 30 ton ha ${ }^{-1}$ menghasilkan pertumbuhan dan produksi yang tertinggi pada tanaman kacang panjang. Penelitian Ezward et al., (2019), perlakuan pupuk solid dengan dosis 30 ton/ha dapat meningkatkan pertumbuhan dan produksi pada tanaman padi. Penelitian mengenai penggunaan berbagai varietas kedelai dikombinasikan dengan pemberian pupuk solid pada budidaya kedelai belum banyak dilakukan terutama di Sumatera Selatan. Padahal kedelai merupakan tanaman yang potensial untuk dikembangkan oleh karena itu perlu dilakukan penelitian penggunaan berbagai varietas kedelai dengan pemberian pupuk solid dan guna melihat interaksi pengaruh berbagai varietas serta pemberian dosis pupuk solid yang berbeda terhadap tanaman kedelai.

\section{$2 \quad$ Metode Penelitian}

Penelitian ini dilaksanakan di lahan petani di Kel. Sukajadi Kec. Talang Kelapa Banyuasin, pada bulan September hingga Desember 2020. Bahan yang digunakan pada penelitian ini adalah benih kedelai varietas Wilis, Tanggamus dan Anjasmoro, pupuk solid, pupuk an-organik (Urea, SP36, KCl), dan pestisida. 
Rancangan yang digunakan pada penelitian ini adalah Rancangan petak terbagi (Split plot design). Masing-masing perlakuan diulang 3 kali dengan perlakuan sebagai berikut : Faktor yang Pertama (Petak Utama) Varietas Kedelai $(\mathrm{V})$ yaitu $\mathrm{V}_{1}=$ Wilis $; \mathrm{V}_{2}=$ Tanggamus dan $\mathrm{V}_{3}=$ Anjasmoro, sedangkan Faktor kedua (Anak Petak) Pupuk Solid (S) yaitu $S_{1}=15$ ton ha-1 $; S_{2}=30$ ton ha ${ }^{-1}$ dan $S_{3}=45$ ton ha ${ }^{-1}$

Tahapan pelaksanaan penelitian: persiapan lahan dibuat petakan ukuran 1,5 $\mathrm{m} \times 2$ m sebanyak 27 petakan, jarak tanam $15 \mathrm{~cm}$ x $20 \mathrm{~cm}$, jarak antar petak $50 \mathrm{~cm}$ dan jarak antar ulangan $1 \mathrm{~m}$. Pemupukan: aplikasi pupuk solid pada 1 minggu sebelum tanam dengan dosis sesuai perlakuan, pemberian pupuk tambahan (Urea, SP36 dan $\mathrm{KCl}$ ) setengah dosis anjuran, pupuk SP36 (100 kg ha-1) dan $\mathrm{KCl}\left(50 \mathrm{~kg} \mathrm{ha}^{-1}\right)$ diberikan satu minggu setelah tanam sedangkan pupuk Urea $\left(50 \mathrm{~kg} \mathrm{ha}^{-1}\right)$ diberikan dua kali (satu minggu setelah tanam $1 / 3$ dosis dan satu bulan setelah tanam $2 / 3$ dosis). Penanaman dilakukan secara tugal membuat lubang tanam dengan kedalaman $2 \mathrm{~cm}$ setiap lubang tanam dimasukkan 2 benih kedelai sesuai dengan perlakuan jenis varietas $\left(\mathrm{V}_{1}=\right.$ Wilis; $\mathrm{V}_{2}=$ Tanggamus dan $\mathrm{V}_{3}=$ Anjasmoro). Pemeliharaan meliputi: penyiraman, penjarangan, penyiangan, pengendalian hama dan penyakit dan pemanenan dilakukan sesuai umur panen varietas kedelai yang digunakan (Wilis 85 hari; Tanggamus 88 hari dan Anjasmoro 82 hari) dengan ciri-ciri polong berubah warna dari hijau menjadi kuning kecoklatan dan retak-retak (polong sudah kelihatan tua), batang berwarna kuning agak cokelat dan gundul. Data-data yang diperoleh dianalisis secara statistik berdasarkan analisis varian pada setiap peubah pengamatan yang diukur dan diuji lanjut bagi perlakuan yang nyata dengan menggunakan metode Uji Beda Nyata Jujur (BNJ) taraf $5 \%$ dan $1 \%$.

\section{Hasil dan Pembahasan}

Hasil analisis keragaman (Anova) menunjukkan bahwa perlakuan varietas dan pupuk solid maupun interaksinya berpengaruh nyata sampai sangat nyata terhadap semua peubah yang diamati (tabel 1).

Tabel 1. Hasil analisis keragaman pengaruh varietas dan pupuk solid terhadap peubah yang diamati

\begin{tabular}{|c|c|c|c|c|}
\hline \multirow{2}{*}{ Peubah yang diamati } & \multicolumn{3}{|c|}{ Perlakuan } & \multirow{2}{*}{ KK (\%) } \\
\hline & $\mathrm{V}$ & $\mathrm{S}$ & 1 & \\
\hline Tinggi tanaman (cm) & ** & ** & ** & 2,35 \\
\hline Jumlah cabang produktif (cabang) & ** & ** & ** & 1,60 \\
\hline Jumlah polong per tanaman (polong) & ** & * & * & 7,64 \\
\hline Berat biji per tanaman (g) & * & ** & ** & 5,44 \\
\hline Berat biji per petak (g) & ** & * & ** & 5,63 \\
\hline Berat 100 biji (g) & ** & ** & ** & 3,49 \\
\hline
\end{tabular}




\section{Pengaruh Jenis Varietas terhadap Peubah yang Diamati}

Hasil sidik ragam menunjukkan bahwa perlakuan varietas berpengaruh nyata sampai sangat nyata terhadap tinggi tanaman, jumlah cabang produktif, jumlah polong per tanaman, berat biji per tanaman, berat biji per petak dan berat 100 biji. Rerata jenis varietas Kedelai terhadap peubah yang diamati dapat dilihat pada tabel 2 .

Tabel 2. Pengaruh varietas terhadap tinggi tanaman (TT), jumlah cabang produktif (JCP), jumlah polong per tanaman (JPPT), berat biji per tanaman (BBPT), berat biji per petak (BBPP) dan berat 100 biji (BSB)

\begin{tabular}{|c|c|c|c|c|c|c|}
\hline Varietas & TT (cm) & $\begin{array}{c}\text { JCP } \\
\text { (cabang) }\end{array}$ & $\begin{array}{c}\text { JPPT } \\
\text { (polong) }\end{array}$ & BBPT (g) & BBPP (g) & BSB (g) \\
\hline \multirow[t]{2}{*}{ Wilis } & $54,55^{a}$ & 7,47 a & $32,21^{a}$ & $84,11^{b}$ & $683,67^{c}$ & $20,97^{c}$ \\
\hline & A & A & A & B & $\mathrm{C}$ & $\mathrm{C}$ \\
\hline \multirow[t]{2}{*}{ Tanggamus } & $57,75^{b}$ & $7,80^{b}$ & $38,16 \mathrm{~b}$ & $47,78^{a}$ & $447,78^{b}$ & 11,22 b \\
\hline & B & B & B & A & B & B \\
\hline \multirow[t]{2}{*}{ Anjasmoro } & $64,32^{c}$ & $9,67^{c}$ & $47,58^{c}$ & 46,00 a & 353,44 a & 9,89 a \\
\hline & C & c & C & $A$ & A & A \\
\hline BNJ 5\% & 1,74 & 0,17 & 3,78 & 0,62 & 35,00 & 0,62 \\
\hline $1 \%$ & 2,33 & 0,22 & 5,05 & 0,83 & 46,82 & 0,83 \\
\hline
\end{tabular}

Keterangan: Angka-angka yang diikuti oleh huruf yang sama pada kolom yang sama berarti berbeda tidak nyata huruf kecil menunjukkan BNJ taraf $5 \%$; huruf kapital menunjukkan BNJ taraf $1 \%$

Hasil penelitian menunjukkan bahwa perlakuan varietas Anjasmoro memberikan pertumbuhan vegetatif yang terbaik dibandingkan dengan varietas Tanggamus dan Wilis. Hal ini dibuktikan dari peubah tinggi tanaman dengan rata-rata $64,32 \mathrm{~cm}$, jumlah cabang produktif dengan rata-rata 9,67 cabang dan jumlah polong per tanaman dengan rata-rata 47,58 polong. Hasil ini menunjukkan adanya perbedaan karakter genetis pada masingmasing varietas yang dipakai. Karakter genetis ini dapat dijadikan sebagai penciri khusus dan akan tetap muncul sebagai pembeda setiap varietas pada setiap fase pertumbuhan. Menurut Sutopo (2008), menyatakan bahwa saat diproduksi kembali, varietas akan menunjukkan sifat-sifat yang akan dapat dibedakan dari yang lainnya. Ditambahkan Agung \& Rahayu (2004), perbedaan sifat genetik menyebabkan terjadinya perbedaan tanggap beberapa varietas terhadap berbagai kondisi lingkungan. Tinggi tanaman tidak hanya menjadi karakter yang terkait dengan jumlah cabang produktif dan jumlah polong per tanaman (Djufry et al., 2012). Tinggi tanaman dapat dipengaruhi oleh varietas, jarak tanam dan pemberian pupuk. Tinggi tanaman kedelai dapat tumbuh tinggi karena jarak tanam yang rapat renggang sehingga terjadi etiolasi pada tanaman karena dapat mempengaruhi penerimaan cahaya matahari langsung ke tanaman kedelai (Rasyid, 2013).

Tanaman kedelai yang memiliki tinggi tanaman yang tinggi dapat meningkatkan jumlah cabang primer sehingga mempengaruhi proses fotosintesis pada tanaman kedelai. Menurut Adie \& Krisnawati (2013), pola percabangan batang kedelai dipengaruhi oleh varietas dan lingkungan seperti panjang hari, jarak tanam, dan kesuburan tanah. Ditambahkan Akhter \& Sneller (1996), menyebutkan bahwa jumlah cabang, jumlah buku 
subur, jumlah polong per tanaman dan ukuran biji merupakan karakter morfologi yang digunakan sebagai kriteria seleksi genotipe kedelai berdaya hasil tinggi dan berperan dalam menentukan hasil kedelai.

Pada tanaman kedelai varietas Wilis memberikan pertumbuhan generatif (produksi) yang terbaik dibandingkan dengan varietas Tanggamus dan Anjasmoro. Hal ini dapat dilihat pada peubah berat biji per tanaman dengan rata-rata $84,11 \mathrm{~g}$, berat biji per petak dengan rata-rata $683,67 \mathrm{~g}$ dan berat 100 biji dengan rata-rata 20,97 g. Hal ini menunjukkan bahwa hasil jumlah biji berbanding lurus dengan berat biji. Banyaknya biji tanaman akan mempengaruhi hasil produksi yang diperoleh. Varietas yang menghasilkan biji lebih dari 100 biji per tanaman dapat dijadikan dalam memodifikasi jumlah biji per tanaman. Menurut Marliah et al., (2012) jumlah biji per tanaman yang lebih dari 100 biji, tergolong kedelai yang berpotensi menghasilkan produksi yang tinggi. Ditambahkan Sarawa et al., (2014), bahwa setiap varietas memiliki keunggulan genetis yang berbedabeda sehingga setiap varietas memiliki produksi yansg berbeda-beda pula, tergantung pada sifat varietas tanaman itu sendiri. Menurut Adie \& Krisnawati (2013), komponen hasil seperti berat 100 biji lebih dominan ditentukan oleh sifat genetik tanaman, karena berkaitan dengan kemampuan tanaman beradaptasi dengan lingkungan tumbuh. Berat 100 biji mencerminkan ukuran biji kedelai, semakin besar ukuran biji semakin beragam ukuran biji dalam satu tanaman.

\section{Pengaruh Dosis Pupuk Solid terhadap Peubah yang Diamati}

Hasil sidik ragam menunjukkan bahwa perlakuan dosis pupuk solid berpengaruh nyata sampai sangat nyata terhadap tinggi tanaman, jumlah cabang produktif, jumlah polong per tanaman, berat biji per tanaman, berat biji per petak dan berat 100 biji. Rerata dosis pupuk solid terhadap peubah yang diamati dapat dilihat pada tabel 3.

Tabel 3. Pengaruh dosis pupuk solid terhadap tinggi tanaman (TT), jumlah cabang produktif (JCP), jumlah polong per tanaman (JPPT), berat biji per tanaman (BBPT), berat biji per petak (BBPP) dan berat 100 biji (BSB)

\begin{tabular}{|c|c|c|c|c|c|c|}
\hline $\begin{array}{c}\text { Pupuk Solid } \\
\left.\text { (to } \mathrm{ha}^{-1}\right)\end{array}$ & TT (cm) & $\begin{array}{c}\text { JCP } \\
\text { (cabang) }\end{array}$ & $\begin{array}{c}\text { JPPT } \\
\text { (polong) }\end{array}$ & BBPT (g) & BBPP (g) & BSB (g) \\
\hline \multirow[t]{2}{*}{15} & $53,35^{a}$ & $7,33^{a}$ & $31,83^{a}$ & $45,67^{a}$ & $351,55^{a}$ & $11,66^{a}$ \\
\hline & A & A & A & A & A & A \\
\hline 30 & $\begin{array}{r}63,35^{c} \\
c\end{array}$ & $\begin{array}{r}9,27^{c} \\
c\end{array}$ & $\begin{array}{r}44,67 \text { b } \\
B\end{array}$ & 71,22 c & $\begin{array}{r}554,89 \text { b } \\
B\end{array}$ & $16,10^{c}$ \\
\hline 45 & $\begin{array}{r}59,92 \text { b } \\
B\end{array}$ & $\begin{array}{r}8,33 \mathrm{~b} \\
\mathrm{~B}\end{array}$ & $\begin{array}{r}41,44 \frac{b}{B} \\
\text { b }\end{array}$ & $\begin{array}{r}62,00 \mathrm{~b} \\
\mathrm{~B}\end{array}$ & $\begin{array}{r}578,44 \text { b } \\
\text { B }\end{array}$ & $\begin{array}{r}14,32 \mathrm{~b} \\
\mathrm{~B}\end{array}$ \\
\hline BNJ 5\% & 1,74 & 0,17 & 3,78 & 4,06 & 35,00 & 0,62 \\
\hline $1 \%$ & 2,33 & 0,22 & 5,05 & 5,43 & 46,82 & 0,83 \\
\hline
\end{tabular}

Keterangan: Angka-angka yang diikuti oleh huruf yang sama pada kolom yang sama berarti berbeda tidak nyata. Huruf kecil menunjukkan BNJ taraf 5\%; huruf kapital menunjukkan BNJ taraf $1 \%$

Hasil penelitian menunjukkan bahwa perlakuan pupuk solid dengan dosis 30 ton ha $^{-1}$ memberikan pertumbuhan vegetatif dan generatif terbaik pada tanaman kedelai dibandingkan dengan perlakuan dosis lainnya. Hal ini dapat dilihat pada peubah tinggi 
tanaman, jumlah cabang produktif, jumlah polong per tanaman, berat biji per tanaman, berat biji per petak dan berat 100 biji menunjukkan perbedaan yang nyata sampai sangat nyata untuk pupuk solid dengan dosis 15 dan 45 ton ha-1. Hal ini berarti pemberian pupuk solid dari masing-masing dosis perlakuan berpengaruh terhadap sesmua peubah yang diamati pada tanaman kedelai. Purnomo et al., (2013), menyatakan bahwa pemupukan bertujuan untuk menambah persediaan unsur-unsur hara yang dibutuhkan tanaman untuk pertumbuhan vegetatif maupun generatif. Tanaman akan tumbuh dengan baik jika unsur hara dalam jumlah cukup sesuai dengan yang dibutuhkan. Ditambahkan Pahan (2008), kandungan hara yang terdapat pada solid memiliki kemampuan untuk memperbaiki kualitas dan kuantitas tanah serta pertumbuhan tanaman, karena solid memiliki decanter yang mengeluarkan $90 \%$ semua padatan dari lumpur sawit dan $20 \%$ padatan terlarut dari minyak sawit. Aplikasinya pada tanaman dapat meningkatkan kandungan fisik, kimia, biologi tanah dan menurunkan kebutuhan pupuk anorganik. Novizan (2005), menyatakan bahwa unsur hara yang berasal dari pupuk organik sebagian kecil dapat langsung dimanfaatkan oleh tanaman, namun sebagian lagi terurai dalam jangka waktu yang lama. Unsur hara yang terurai tersebut kemudian dapat dimanfaatkan oleh tanaman. Dengan bantuan jasad renik didalam tanah bahan organik akan diubah menjadi bentuk sederhana yang dapat diserap tanaman.

\section{Pengaruh Interaksi Jenis Varietas dan Dosis Pupuk Solid terhadap Peubah yang Diamati}

Hasil sidik ragam menunjukkan bahwa perlakuan interaksi antara jenis varietas dan dosis pupuk solid berpengaruh nyata sampai sangat nyata terhadap tinggi tanaman, jumlah cabang produktif, jumlah polong per tanaman, berat biji per tanaman, berat biji per petak dan berat 100 biji. Rerata interaksi antara jenis varietas dan dosis pupuk solid terhadap peubah yang diamati dapat dilihat pada tabel 4.

Tabel 4. Pengaruh interaksi jenis varietas dan dosis pupuk solid terhadap tinggi tanaman (TT), jumlah cabang produktif (JCP), jumlah polong per tanaman (JPPT), berat biji per tanaman (BBPT), berat biji per petak (BBPP) dan berat 100 biji (BSB)

\begin{tabular}{|c|c|c|c|c|c|c|}
\hline Perlakuan & TT (cm) & $\begin{array}{c}\text { JCP } \\
\text { (cabang) }\end{array}$ & $\begin{array}{c}\text { JPPT } \\
\text { (polong) }\end{array}$ & $\begin{array}{c}\text { BBPT } \\
\text { (g) }\end{array}$ & BBPP $(g)$ & BSB (g) \\
\hline $\mathrm{V}_{1} \mathrm{~S}_{1}$ & $46,16^{a}$ & $6,60^{a}$ & $26,17^{a}$ & $65,00^{d}$ & $501,33^{c}$ & $46,16^{a}$ \\
\hline$V_{1} S_{2}$ & $60,62^{d}$ & 8,13 de & $35,27^{b}$ & 94,67 e & $766,67^{d}$ & $60,62^{d}$ \\
\hline$V_{1} S_{3}$ & 56,88 bc & $7,67^{c}$ & $35,20^{b}$ & $92,67^{\mathrm{e}}$ & $783,00 \mathrm{~d}$ & 56,88 bc \\
\hline $\mathrm{V}_{2} \mathrm{~S}_{1}$ & $54,67^{b}$ & $7,13^{b}$ & $27,27^{a}$ & $37,00 \mathrm{ab}$ & $287,00^{a}$ & $54,67^{b}$ \\
\hline $\mathrm{V}_{2} \mathrm{~S}_{2}$ & $60,405^{d}$ & $8,40^{e}$ & 47,27 de & $65,00 \mathrm{~d}$ & $508,00^{c}$ & $60,40^{d}$ \\
\hline $\mathrm{V}_{2} \mathrm{~S}_{3}$ & $58,19 \mathrm{~cd}$ & $7,87 \mathrm{~cd}$ & $39,93 \mathrm{bc}$ & $41,33 \mathrm{ab}$ & $548,33^{c}$ & $58,19 \mathrm{~cd}$ \\
\hline$V_{3} S_{1}$ & $59,23 \mathrm{~cd}$ & 8,27 de & $42,07 \mathrm{~cd}$ & 35,00 a & 266,33 a & $59,23 \mathrm{~cd}$ \\
\hline $\mathrm{V}_{3} \mathrm{~S}_{2}$ & $69,03^{f}$ & $11,27 \mathrm{~g}$ & $51,47^{e}$ & $54,00 \mathrm{~cd}$ & $390,00 \mathrm{~b}$ & $69,03^{f}$ \\
\hline $\mathrm{V}_{3} \mathrm{~S}_{3}$ & $64,69 e$ & $9,47^{f}$ & $49,20^{e}$ & $49,00 \mathrm{bc}$ & $404,00^{b}$ & $64,69 e$ \\
\hline BNJ 5\% & 2,43 & 0,25 & 5,27 & 9,82 & 48,89 & 0,86 \\
\hline $1 \%$ & 3,08 & 0,31 & 6,67 & 12,42 & 61,88 & 1,09 \\
\hline
\end{tabular}

Keterangan: Angka-angka yang diikuti oleh huruf yang sama pada kolom yang sama berarti berbeda tidak nyata 
Hasil sidik ragam menunjukkan bahwa terdapat interaksi antara perlakuan varietas dan pupuk solid. Interaksi ini memberikan pengaruh sangat nyata terhadap tinggi tanaman kedelai. Kombinasi perlakuan yang menghasilkan tinggi tanaman paling tinggi adalah varietas Anjasmoro dan pupuk solid dosis 30 ton ha-1 dengan rata-rata 69,03 cm. Sementara itu nilai terendah terdapat pada kombinasi perlakuan varietas Wilis dan pupuk solid dosis 15 ton ha ${ }^{-1}$ dengan rata-rata $46,16 \mathrm{~cm}$. Penampilan karakter setiap varietas ditentukan oleh faktor genetik dari varietas tersebut. Perbedaan genetik tersebut menyebabkan perbedaan penampilan fenotifik tanaman dengan menampilkan sifat dan ciri yang khusus yang berbeda antara satu dengan yang lainnya dengan pengaruh lingkungan (Siregar, 2009). Ditambahkan Taufiq \& Sundari (2012), tanaman dapat memberikan respon positif dan negatif terhadap perubahan lingkungan tumbuh. Respon yang beragam tersebut menimbulkan terjadinya interaksi antara lingkungan dan genotip yang dimiliki. Respon dapat diketahui dari perubahan fisik tanaman berupa perubahan pertumbuhan dan perubahan fenotipik tanaman.

Hal ini menunjukkan bahwa interaksi antara varietas dan pemberian pupuk solid dosis 30 ton ha-1 dapat meningkatkan tinggi tanaman. Selain itu peran pupuk solid 30 ton ha $^{-1}$ merupakan dosis yang cukup untuk membantu ketersediaan unsur hara pada tanaman kedelai dan juga memperbaiki struktur tanah karena memiliki kandungan organik sehingga membantu pertumbuhan dan produksi dengan maksimal. Penambahan pupuk solid baik untuk perkembangan mikroorganisme tanah sehingga akhirnya terjadi perbaikan sifat fisik tanah. Perbaikan sifat fisik tanah akan menambah kualitas porositas tanah dan kemampuan tanah dalam menahan air. Tanah yang diberi pupuk solid juga berdampak positif terhadap perbaikan sifat kimia tanah karena pupuk solid mengandung unsur hara makro maupun mikro. Pupuk solid juga dapat meningkatkan kemampuan tanah dalam melepas unsur hara $\mathrm{P}$ yang terjerap pada mineral tanah. Sejalan dengan pendapat Munawar (2011), pemberian bahan organik dapat melepaskan unsur hara $P$ perombakan bahan organik juga menghasilkan asam-asam organik seperti oksalat dan sitrat.

Hasil sidik ragam menunjukkan bahwa terdapat interaksi antara perlakuan varietas dan pupuk solid. Interaksi ini memberikan pengaruh sangat nyata terhadap jumlah cabang produktif. Kombinasi perlakuan yang menghasilkan jumlah cabang produktif terbanyak adalah varietas Anjasmoro dan pupuk solid dosis 30 ton ha ${ }^{-1}$ dengan rata-rata 11,27 cabang. Sementara itu nilai terendah terdapat pada kombinasi perlakuan varietas Wilis dan pupuk solid dosis 15 ton ha-1 dengan rata-rata 6,60 cabang. Cabang pada tanaman kedelai mempunyai hubungan yang sangat erat dengan hasil yang diperoleh, karena posisi polong kedelai berada di cabang tanaman atau ketiak daun. Semakin banyak jumlah cabang maka potensi munculnya polong akan semakin banyak (Widodo, 2010). 
Secara umum pemberian pupuk solid dengan dosis 30 ton ha ${ }^{-1}$ merupakan dosis yang efektif untuk meningkatkan pertumbuhan tanaman kedelai. Varietas Anjasmoro memiliki jumlah cabang produktif lebih banyak sesuai dengan deskripsinya (Balitkabi, 2015). Jumlah cabang per tanaman dapat ditingkatkan dengan pemberian pupuk yang dalam aplikasinya tidak boleh berlebihan dan dosis tertentu saja, penggunaan pupuk tersebut akan dapat memberikan pertumbuhan yang optimal (Sutedjo, 2010; Khaim et al., 2013).

Varietas Wilis mampu mencapai jumlah cabang produktif yang optimal 6,60 cabang pada pemberian pupuk solid dosis 15 ton ha ${ }^{-1}$. Hal ini diduga karena pemberian pupuk solid yang diberikan walaupun dengan dosis yang rendah dan memiliki kandungan hara yang relatif rendah tetapi telah mampu memenuhi kebutuhan hara pendukung pertumbuhan varietas Wilis. Varietas Wilis tergolong varietas kedelai yang berbiji kecil dengan tinggi tanaman dan percabangan yang lebih rendah dibandingkan dengan varietas Anjasmoro dan Tanggamus. Oleh sebab itu dalam masa pertumbuhannya akan memerlukan asupan hara yang lebih sedikit pula. Menurut Sarief (2005), menyatakan bahwa setiap varietas akan membutuhkan pupuk yang berbeda jumlahnya untuk menunjang pertumbuhan dan menghasilkan produksi yang lebih baik. Masing-masing varietas akan memberikan respon pertumbuhan dan tingkat produksi yang berbeda-beda pula.

Hasil penelitian menunjukkan bahwa perlakuan interaksi varietas dan pupuk solid menghasilkan rata-rata berat 100 biji terbanyak pada varietas Anjasmoro dengan pupuk solid dosis 45 ton ha-1 $(64,69 \mathrm{~g})$ dan terendah pada varietas Wilis dengan pupuk solid dosis 15 ton ha-1 $(46,16 \mathrm{~g})$. Pemberian pupuk solid meningkatkan berat 100 biji varietas Anjasmoro, Tanggamus dan Wilis. Pada varietas Anjasmoro peningkatan dosis pupuk solid diikuti peningkatan berat 100 biji. Hasil ini menunjukkan bahwa masing-masing varietas menunjukkan respon yang berbeda-beda terhadap pupuk solid yang diberikan. Menurut Fernandes et al., (2003), bahwa pemberian bahan organik pada tanaman memberikan hasil yang lebih baik dan kualitas yang lebih baik. Hal ini disebabakan karena bahan organik selain mengandung unsur hara makro juga mengandung unsur hara mikro yang sangat dibutuhkan oleh tanaman. Ditambahkan Rosmarkam \& Yuwono (2011), menyatakan bahwa bahan organik dalam proses mineralisasi akan melepaskan hara tanaman yang lengkap yaitu $\mathrm{N}, \mathrm{P}, \mathrm{K}, \mathrm{Ca}, \mathrm{Mg}$ dan $\mathrm{S}$ serta unsur hara mikro. Ketersediaan unsur hara dalam tanah memungkinkan pertumbuhan dan produksi tanaman berlangsung dengan baik. Komponen hasil seperti berat 100 biji lebih dominan oleh sifat genetik tanaman, karena berkaitan dengan kemampuan tanaman beradaptasi dengan lingkungan tumbuh. Berat 100 biji mencerminkan ukuran biji kedelai, semakin besar ukuran biji semakin beragam ukuran biji dalam satu tanaman (Adie \& Krisnawati, 2013). 
Hasil penelitian menunjukkan bahwa perlakuan interaksi varietas dan pupuk solid menghasilkan rata-rata berat biji per petak terbanyak pada varietas Wilis dengan pupuk solid dosis 45 ton ha-1 $783,00 \mathrm{~g})$ dan terendah pada varietas Anjasmoro dengan pupuk solid dosis 15 ton ha-1 (266,33 g). Mengamati daya adaptasi yang sangat baik dan pertumbuhan tanaman sangat optimal, perolehan hasil biji yang diharapkan sebelumnya lebih tinggi. Hasil biji kedelai telah mendekati rata-rata hasil biji pada deskripsi varietas unggul kedelai yang dikeluarkan oleh Balai Penelitian Tanaman Aneka Kacang dan Umbi (Balitkabi, 2017).

\section{$4 \quad$ Kesimpulan}

Berdasarkan hasil penelitian di lapangan dan analisis keragaman dapat disimpulkan bahwa varietas Anjasmoro memberikan hasil terbaik pertumbuhan tanaman kedelai dengan tinggi tanaman tertinggi $(64,32 \mathrm{~cm})$, jumlah cabang produktif terbanyak (9,67 cabang) sedangkan varietas Wilis memberikan produksi terbaik tanaman kedelai dengan berat biji per tanaman terbaik $(84,11 \mathrm{~g})$, berat biji per petak terbaik $(683,67 \mathrm{~g})$. Pupuk solid dengan dosis 30 ton ha ${ }^{-1}$ memberikan hasil terbaik terhadap pertumbuhan dan produksi tanaman kedelai. Interaksi antara varietas Wilis dan pupuk solid dosis 30 ton ha $^{-1}$ memberikan hasil terbaik terhadap produksi tanaman kedelai sebesar 783,00 g/petak atau setara dengan 2,08 ton $\mathrm{ha}^{-1}$.

\section{Daftar Pustaka}

Adie, M. M., \& Krisnawati, A. (2013). Biologi Tanaman Kedelai. In Kedelai: Teknik Produksi dan Pengembangan. Cetakan ke-2 (pp. 45-73). Bogor: Badan Penelitian dan Pengembangan Pertanian. Pusat Penelitian dan Pengembangan Tanaman Pangan.

Agung, T., \& Rahayu, A. Y. (2004). Analisis Efisiensi Serapan N, Pertumbuhan dan Hasil Beberapa Kultivar Kedelai Unggul Baru dengan Cekaman Kekeringan dan Pemberian Pupuk Hayati. Jurnal Agrosains, 6(2), 70-74.

Akhter, M., \& Sneller, C. H. (1996). Yield and Yield Components of Early Maturing Soybean Genotypes in the Mid-South. Crop Science, 36(4), 877-882. https://doi.org/https://doi.org/10.2135/cropsci1996.0011183X0036000400010x Badan Pusat Statistik.
Bps.Go.Id/Subject/53/Tanaman_pangan.Html Diakses Januari 2020.

Balitkabi. (2015). Deskripsi Varietas Unggul Kedelai. Malang: Balitkabi.

Balitkabi. (2017). Deskripsi Varietas Unggul Kacang-Kacangan dan Umbi-umbian. Malang: Balitkabi.

Dinas Pertanian Tanaman Pangan dan Hortikultura Provinsi Sumatera Selatan. (2019). Luas Panen Rata-rata Produksi per hektar dan Produksi Tanaman Pangan menurut Komoditas di Provinsi Sumatera Selatan. 
Djufry, F., Lestari, M. S., \& Kasim, A. (2012). Pengujian Galur-Galur Harapan Kedelai Produktivitas Tinggi di Dua Kabupaten Provinsi Papua. Prosiding Seminar Hasil Penelitian Tanaman Aneka Kacang Dan Umbi . Tema: Inovasi Teknologi Dan Kajian Ekonomi Komoditas Aneka Kacang Dan Umbi Mendukung Empat Sukses Kementerian Pertanian. Bogor 15 November 2011, 103-111. Bogor: Pusat Penelitian dan Pengembangan Tanaman Pangan - Badan Penelitian dan Pengembangan Pertanian.

Ezward, C., Dadang Kurniawan, \& Susanto, H. (2019). Pengaruh Pemberian Berbagai Dosis Limbah Padat Kelapa Sawit terhadap Pertumbuhan dan Produksi Tanaman Padi (Oryza sativa L.) dengan Metode Jajar Legowo 4 : 1. Jurnal Sains Agro, 4(2), 1-7. https://doi.org/http://dx.doi.org/10.36355/jsa.v4i1.247

Fernandes, A. L. T., Rodrigues, G. P., \& Testezlaf, R. (2003). Mineral and Organomineral Fertigetion in Relation to Quality of Greenhouse Cultivated Melon. Scientia Agricola, 60(1), 149-154. https://doi.org/10.1590/s0103-90162003000100022

Hasanuddin, A., Hidajat, J. R., \& Patohardjono, S. (2005). Kebijakan Program Penelitian Kacang-kacangan Potensial. Bogor: Puslitbangtan.

Idris, \& Okalia, D. (2018). Efek Sisa Kompos Solid Plus (Kosplus) terhadap Pertumbuhan dan Produksi Tanaman Kacang Panjang (Vigna sinensis L.) pada Tanah Ultisol. Primordia, 14(1), 6-16. https://doi.org/https://doi.org/10.37303/.v14i1.38

Khaim, S., Chowdhury, M. A. H., \& Saha, B. K. (2013). Organic and Inorganic Fertilization on The Yield and Quality of Soebean. Journal of the Bangladesh Agricultural University, 11(1), 23-28. https://doi.org/10.3329/jbau.v11i1.18199

Marliah, A., Hidayat, T., \& Husna, N. (2012). Pengaruh Varietas dan Jarak Tanam terhadap Pertumbuhan Kedelai (Glycine max (L) Merrill). Jurnal Agrista, 16(1), 22 28.

Martodireso, \& Suryanto. (2001). Pemupukan Organik Hayati. Yogyakarta: Kanisius.

Munawar, A. (2011). Kesuburan Tanah dan Nutrisi Tanaman. Bogor: IPB Press.

Novizan. (2005). Petunjuk Pemupukan yang Efektif. Jakarta: Agro Media Pustaka.

Pahan, I. (2008). Panduan Lengkap Kelapa Sawit: Manejemen Agribisnis dari Hulu hingga Hilir. Jakarta: Penebar Swadaya.

Purnomo, R., Santoso, M., \& Heddy, S. (2013). Pengaruh Berbagai Macam Pupuk Organik dan Anorganik terhadap Pertumbuhan dan Hasil Tanaman Mentimun (Cucumis sativus L.). Jurnal Produksi Tanaman, 1(3), 93-100.

Pusat Penelitian Kelapa Sawit. (2009). Hasil Analisis Unsur Hara Kompos Solid. Medan: Sumatera Utara.

Rasyid, H. (2013). Peningkatan Produksi dan Mutu Benih Kedelai Varietas Hitam Unggul Nasional sebagai Fungsi Jarak Tanam dan Pemberian Dosis Pupuk P. Jurnal Gamma, 8(2), 46-63.

Riawati, Rasyad, A., \& Wardati. (2016). Respon Empat Varietas Kedelai (Glycine max (L) Merrill) terhadap Pemberian Dosis Pupuk Fospor. JOM Faperta, 3(1).

Rosmarkam, A., \& Yuwono, N. W. (2011). Ilmu Kesuburan Tanah. Yogyakarta: Kanisius.

Sabrina, A. I. M., Karyawati, A. S., \& Nihayati, E. (2018). Peningkatan Hasil Tanaman Kedelai (Glycine max (L) Merrill) Melalui Penambahan Urea pada Saat Awal Berbunga. Jurnal Produksi Tanaman, 6(8), 1698-1703.

Sarawa, Anas, A. A., \& Asrida. (2014). Pola Distribusi Fotosintat pada Fase Vegetatif Beberapa Varietas Kedelai pada Tanah Masam di Sulawesi Tenggara. Jurnal Agroteknos, 4(1), 26-31. 
ISSN 2354-7251 (print)

Sari, D. K., Hasanah, Y., \& Simanungkalit, T. (2014). Respon Pertumbuhan dan Produksi Beberapa Varietas Kedelai (Glycine max (L) Merill) dengan Pemberian Pupuk Organik Cair. Jurnal Online Agroekoteknologi, 2(2), 653-661. Retrieved from http://www.tjyybjb.ac.cn/CN/article/downloadArticleFile.do?attachType=PDF\&id=998 7

Sarief, E. S. (2005). Kesuburan dan Pemupukan Tanah Pertanian. Bandung: Pustaka Buana.

Siregar, A. J. (2009). Tanggap Beberapa Varietas Kedelai (Glycine max (L) Merrill) pada Tinggi Pemberian Pupuk Organik Cair. Skripsi. Program Studi Pemuliaan Tanaman Departemen Budidaya Pertanian. Fakultas Pertanian. Universitas Sumatera Utara, Medan.

Sutedjo, M. M. (2010). Pupuk dan Cara Pemupukan. Jakarta: Rineka Cipta.

Sutopo, L. (2008). Teknologi Benih. Jakarta: Raja Grafindo Persada.

Taufiq, A., \& Sundari, T. (2012). Respon Tanaman Kedelai terhadap Lingkungan Tumbuh. Buletin Palawija, (23), 13-26. https://doi.org/10.21082/bulpalawija.v0n23.2012.p1326

Widodo, R. (2020). Pengaruh Konsentrasi Pupuk Organik Cair dan Jarak Tanam terhadap Pertumbuhan dan Hasil Kedelai Hitam (Glycine soya (L.) Sieb \& Succ.). Skripsi. Jurusan Agronomi. Fakultas Pertanian. Universitas Sebelas Maret. Surakarta. 